\title{
Quality Evaluation of Flaxseed Obtained from Different Locations ${ }^{\dagger}$
}

\author{
Devendra Kumar Mishra (1) and Himani Awasthi *
}

check for

updates

Citation: Mishra, D.K.; Awasthi, H. Quality Evaluation of Flaxseed Obtained from Different Locations. Biol. Life Sci. Forum 2021, 4, 70. https://doi.org/10.3390/IECPS202008754

Academic Editor: Yoselin

Benitez-Alfonso

Published: 1 December 2020

Publisher's Note: MDPI stays neutral with regard to jurisdictional claims in published maps and institutional affiliations.

Copyright: (C) 2020 by the authors Licensee MDPI, Basel, Switzerland This article is an open access article distributed under the terms and conditions of the Creative Commons Attribution (CC BY) license (https:// creativecommons.org/licenses/by/ $4.0 /)$.
Amity Institute of Pharmacy, Amity University Uttar Pradesh Lucknow Campus,

Lucknow 226028, Uttar Pradesh, India; devendra4747@gmail.com

* Correspondence: hawasthi@lko.amity.edu; Tel.: +91-995-6775-093

+ Presented at the 1st International Electronic Conference on Plant Science, 1-15 December 2020; Available online: https://iecps2020.sciforum.net/.

\begin{abstract}
The aim of this study is to review the quality of flaxseed obtained from different geographical locations. The review is based on the previous studies which confirm that climatic conditions provide the impact on the plant growth and their quality as well. Geographic investigations of plant molecular variety can give substantial data of plant growth and upgrade plant germplasm, medicinal values, and the uses, yet such examinations are deficient in cultivated flax (Linum usitatissimum L.). Flax is the third biggest fibre harvest naturally and one among the five significant oil crops on the earth. Flax is often utilized as a model plant for the best plants on account of its compact size and self-fertilization characteristics. Flaxseed yields shifted incredibly due to climate and soil type, yet these conditions demonstrated next to no impact on plant thickness. There is a higher variety of generative plant parts seen by cultivated flax and more vegetative pieces of the plant were seen in pale flax fluctuates. The scope of variety, hereditarily based variety, heritability, and connection of a few characters are thought of, particularly concerning the impact of domestication. Higher developing season temperatures in different locations can impact the efficacy of agricultural, income of the farm and food security. Postponement in planting prompted an expansion in natural temperature during conceptive development of harvest bringing about lower seed quality. The outcomes demonstrated that the planting climate influences the development characteristics, yield, and its segment as well as the yield of oil. These findings are important for understanding flax domestication and are also helpful in grouping intraspecific variety of cultivated flax, setting up a centre subset of the flax assortment, and investigating new wellsprings of qualities for flax improvement.
\end{abstract}

Keywords: Linum usitatissimum; growth performance; cultivators; seed and oil yields; genetic diversity

\section{Introduction}

During the last years, there has been an expanded interest by industry, horticulture and plant reproducers in flax because of its utilization as a common crude material for modern purposes [1]. The terms flaxseed (Linum usitatissimum L.) and linseed are often used interchangeably [2]. Moderate temperature $\left(21-27^{\circ} \mathrm{C}\right)$ is required during the vegetative and conceptive stage; high temperature $\left(>32^{\circ} \mathrm{C}\right)$ with dampness stress during the blooming stage decreases seed yield, just as developed in four agro-climatic zones of India [3]. Flaxseed is rising as a significant oilseed in view of the presence of $\alpha$-linolenic acid (ALA), $18: 3 n-3$ [4]. It contains $35-45 \%$ oil, of which $45-52 \%$ is ALA [5]. The valuable impacts of omega-3 unsaturated fats on human wellbeing are entrenched [6]. The alluring, reddishbrown coloured oval seeds of flax add a charming nutty taste to items, additional surface and great sustenance to bread and other prepared products [7]. Flax has been utilized in multi-grain oats and nibble nourishments. Flax is an old financial yield developed as an oil, fibre or double reason crop [8]. Flax additionally conveys the advantages of its dissolvable fibre, lignans, omega-3 unsaturated fat blend and protein [7]. Since over half of linolenic acid is present in the flaxseeds oil, it is appropriate for modern use in defensive coatings, for example, polishes, lacquers, stains, and paints [9]. The ALA decreases the danger of 
cancer, rheumatoid joint inflammation, osteoporosis and CVD disease [5]. The advantages of omega- 3 unsaturated fats to insects, horses, pigs, and different creatures might be in keeping youthful creatures from creating contaminations [7].

It is adjusted to a wide scope of conditions, with India, Argentina and Canada being among the world's biggest producers [10]. Flax is viewed as a cool-season crop; air temperature underneath $10{ }^{\circ} \mathrm{C}$ in the spring may repress development and improvement, which can postpone blossoming [11]. There is an impact on food security, income of the farm and productivity of agricultural due to higher growing season temperatures [12] Kumar et al. (2019) [13] reported that flaxseed shows a great affinity in its constituents when it was grown between the average temperature of $25.3^{\circ} \mathrm{C}$, while the minimum monthly average temperature was $4.4^{\circ} \mathrm{C}$. The cultivating date and its effect on flax execution is connected to the climate, with right-on-time or later cultivated flax having a higher possibility of experiencing frost or drought season; consequently, prior cultivating brought about most noteworthy seed yield [9]. The nature of harvest produces during developing and capacity is controlled by common conditions and anthropogenic components [7]. As of now, fibre flax cultivars are basically filled in certain areas of China, Russia and northern Europe, while particular flax assortments are generally filled in cool, calm areas of Canada, the USA, Russia, China, India and Argentina [3]. There are vast varieties of the flaxseed obtained from different geographical regions; thus, the information about the suitable climatic conditions is very much important before the flax assortment, and also when we are investigating new wellsprings of qualities for the improvement of flax.

\section{Methods of Cultivation}

- Position in the pivot cycle: To maintain a strategic distance from the weakening of the ground and the spread of cryptogamic illnesses, flax must not be developed in similar soil for more than six or seven years [14].

- Breeding: Linum usitatissimum L. species is a self-pollinated yield, and its hereditary improvement can be helped out through ordinary rearing strategies for hybridization and choice from one perspective or using new procedures; for example, transformation on other, tissue culture, mutation, haploidy, and interspecific hybridization are carried out in Canada, China, USA and other countries [15]. In India, the major regions of Assam, Sikkim, Himachal Pradesh, Uttarakhand, etc. are major flaxseed growing states in the country [16].

- Harvesting: It is generally carried out when the plants arrive at the ideal maturing degree in between the month of August-September. Flax that is pulled too soon contains exceptionally fine yet feeble filaments. Then again, in overripe flax, earthy colored stems are solid but fragile, creating a lot of unwanted short filaments, particularly in the USA and China [17]. In India, the crops harvested during the winter season (September-October) after the flowering stage (at early pod formation stage) were found to have more potent constituents [13].

\section{Factor Affecting the Quality of the Flaxseed}

Mohamed Al-Doori, 2012 described that in both seasons of the mid-November flaxseed, the belinka genotype shows the lowest number of yield of seeds per plant, capsule produces per hectare, but the plantation of strain genotype yields the maximum total seed and highest number of capsules per plant in the first November per hectare-in both seasons [18]. Casa et al. (1999) reported that the extent of seeds that formed into developing plants changed impressively from year to year and would in general diminish with the seed rate [10]. Mirshekari et al. (2012) showed that the harvest index was the most extreme in first planting date and diminished with deferred planting dates on the grounds that the grain arrangement stages harmonized with positive lower temperature, while by a late-planting date flaxseed experienced serious heat pressure during grain development, prompting an irregular turn of events and poor production [9]. 


\section{Outcome and Discussion}

Fibre flax is delivered in the temperate to cooler locales of Europe and Asia and a restricted degree. Table 1 gives the overall production of fibre flax concerning absolute zone and yield [16].

Table 1. Area, Production and Yield of Major Flaxseed Growing Countries.

\begin{tabular}{|c|c|c|c|c|c|c|c|c|c|c|}
\hline \multirow{2}{*}{ Serial No. } & \multirow{2}{*}{ Country } & \multicolumn{3}{|c|}{ Area (lakh ha) } & \multicolumn{3}{|c|}{ Production (lakh MT) } & \multicolumn{3}{|c|}{ Yield (kg/ha) } \\
\hline & & 2012-2013 & $2013-2014$ & 2014-2015 & 2012-2013 & 2013-2014 & 2014-2015 & 2012-2013 & 2013-2014 & 2014-2015 \\
\hline & World & 25.72 & 22.97 & 26.01 & 20.62 & 22.99 & 25.65 & 802 & 1001 & 986 \\
\hline 1 & Ethiopia & 1.28 & 0.96 & 0.82 & 1.22 & 0.88 & 0.83 & 955 & 920 & 1010 \\
\hline 2 & USA & 1.36 & 0.73 & 1.26 & 1.47 & 0.82 & 1.62 & 1083 & 1123 & 1285 \\
\hline 3 & India & 4.31 & 3.38 & 3.6 & 1.52 & 1.47 & 1.41 & 353 & 435 & 392 \\
\hline 4 & China & 3.18 & 3.13 & 3.1 & 3.91 & 3.99 & 3.5 & 1228 & 1275 & 1129 \\
\hline 5 & Russia & 5.58 & 4.38 & 4.42 & 3.69 & 3.26 & 3.93 & 661 & 743 & 890 \\
\hline 6 & Canada & 3.84 & 4.22 & 6.21 & 4.89 & 7.31 & 8.72 & 1272 & 1731 & 1405 \\
\hline
\end{tabular}

Source: Oilseeds Statistics: A Compendium-2015, ICAR-Indian Institute of Oilseeds Research, Hyderabad.

As per the data of ICAR, Oilseeds Statistics, there is an increasing percentage of yield obtained from Canada followed by China, USA and other countries as show in Figure 1. The main cause of influence in the percentage of yield obtained from different locations is due to climatic variation, time of sowing and the harvesting time of the plants. The ideal cultivation or harvesting time of the plants is after the flowering stage.

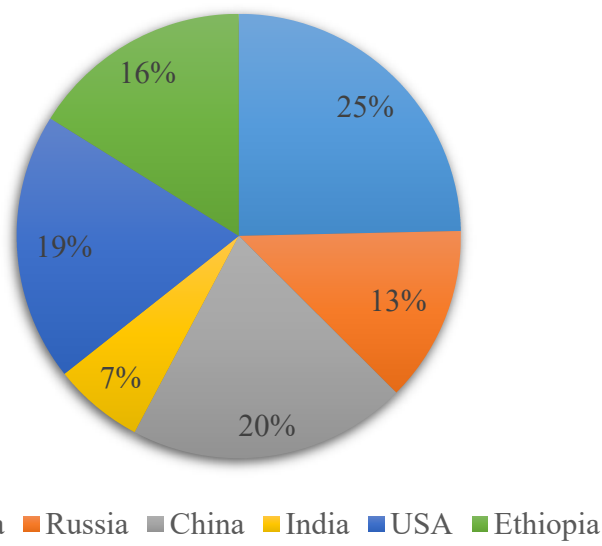

Figure 1. The yield of Major Flaxseed Growing Countries.

Flaxseed is cultivated in more than 50 countries from where the average amount grown on an area is 24.09 lakh ha (average: 2012-15), average production is 23.09 lakh tonne (average: 2012-15) and average productivity is $930 \mathrm{~kg} / \mathrm{ha}$ (average: 2012-15).

The sowing of plants at the cool temperature and different techniques followed in various countries such as European countries follows different types of diallel crosses and India follows pure line selection, hybridization or pedigree method that enhances the quality of flaxseed. The sowing and cultivation or harvesting time play a major role in the development of active constitutes in the seeds. As per the study, the maximum yields $(25 \%)$ were obtained from Canada, which shows a greater potency of seeds from the Canadian region. As per the data of Siemens, 2017 [19], the Canadian seeds of the flaxseed show a greater quality of their content, as shown in Table 2. 
Table 2. Contents of Canadian flaxseeds.

\begin{tabular}{ccc}
\hline Serial No. & Quality Parameter & Quantity \\
\hline 1 & Oil Content & 46.1 \\
2 & Protein Content & 23.2 \\
3 & Iodine value & 192.5 \\
4 & Free fatty acids & 0.18 \\
\hline
\end{tabular}

Source: Quality of western Canadian flaxseed, Canadian Grain Commission, 2017.

The latest data show the enriching quality of the flaxseed obtained from the Canadian region in the year of 2017. Oil and protein content gives a quantitative assessment of the estimation of the seed as a wellspring of oil and the subsequent meal as a wellspring of protein for the feed of animal. ALA is an omega-3 fatty acid can assume a significant function in keeping up great wellbeing in animals and people. It is the principal factor in the expanded utilization of entire and ground flaxseed in grains and prepared products, and flaxseed oil in servings of mixed salads. Iodine esteem is a proportion of the general unsaturation of the oil and can be determined from the unsaturated fat structure. Oils with higher iodine esteem, i.e., with more unsaturation, polymerize more quickly with contact with air. In flaxseed, iodine esteem is legitimately identified with the measure of ALA present in the oil. ALA is one of the main quality elements for mechanical use as it is liable for the vast majority of flaxseed oil's drying properties. There are several health benefits of the flaxseed depending upon the active constituents which help in the treatment. As per the data of Siemens, 2017 [19], the Canadian seeds of flaxseed show a greater quality of their active constituents, as shown in Table 3.

Table 3. Active constituents of Canadian flaxseeds.

\begin{tabular}{ccc}
\hline Serial No. & Quality Parameter & Quantity \\
\hline 1 & Palmitic acid & 5.0 \\
2 & Stearic acid & 3.5 \\
3 & Oleic acid & 17.8 \\
4 & Linoleic acid & 15.0 \\
5 & $\alpha$-Linolenic acid & 57.7 \\
\hline
\end{tabular}

Source: Quality of western Canadian flaxseed, Canadian Grain Commission, 2017.

Additionally, as per the data of Siemens, 2017 [19], the seeding of the flax was started from the end of April and was completed by mid-May. In that time, there were drought-like conditions when the data was reported during the growing season. Approximately $90 \%$ of the crop was harvest by the middle of October. The highest active constituents can be obtained when it is grown in the temperature range $24-26^{\circ} \mathrm{C}$.

\section{Conclusions}

Flaxseed is considered to be the most valuable food nowadays due to the various immerging trends of its use in various disorders. Flaxseed has the potency to act against cancer, menopausal syndrome, skin, gastrointestinal disorder, brain damage, etc. The flaxseed shows a dramatic change in the pattern of the location, as it shows a greater potency in the seed from cool climatic regions in comparison to the seeds obtained from hot regions. When it was planted in spring, flax developed rapidly by virtue of the positive stickiness and warmth around at that time. The development cycle is typically 100 days. An ascent in temperature combined with dryness speeds up the development cycle; however, this lessens the size of the plant. The majority of the yield is developed north of scope $50^{\circ} \mathrm{N}$; hence, both the oil substance and iodine number are moderately high. The quality of the flaxseed can be also enhanced by the use of various biofertilizers and the main factor that influences the quality is the sowing and harvesting days along with the method of doing it. On the basis of the reported literature, it was found that flaxseed obtained from the Canadian region shows greater quality. There is an almost $25 \%$ of world yield of flaxseed 
obtained from Canada and the content of the constituent is also high among other growing countries. Favourable harvesting conditions for the growth and development of beneficial active constituents from the flaxseed is based on the temperature and it is well grown in the temperature range of $24-26^{\circ} \mathrm{C}$. Thus, it can be concluded that the sample obtained from a cooler climate was more potent and has more chemical constituents, which will help in the further study of flaxseed.

Supplementary Materials: The poster presentation is available online at https:/ /www.mdpi.com/ article/10.3390/IECPS2020-08754/s1.

Institutional Review Board Statement: Not Applicable.

Informed Consent Statement: Not Applicable.

Data Availability Statement: Data available in a publicly accessible repository that does not issue DOIs. Publicly available datasets were analyzed in this study. This data can be found here: (https:// www.grainscanada.gc.ca/en/grain-research/export-quality/oilseeds/flaxseed/2017/flaxseed-qualityreport-17-1.html and another link are https:/ /icar-iior.org.in/index.php/oilseeds-database).

Conflicts of Interest: The authors declare no conflict of interest.

Abbreviations
The following abbreviations are used in this manuscript:
ALA $\quad \alpha$-linolenic acid
CVD Cardiovascular disease
USA $\quad$ United State of America
$\mathrm{Ha} \quad$ hectares
$\mathrm{Mt} \quad$ Metric Tons
$\mathrm{Kg} /$ ha

\section{References}

1. Diederichsen, A.; Hammer, K. Variation of cultivated flax (Linum usitatissimum L. subsp.usitatissimum) and its wild progenitor pale flax (subsp.angustifolium (Huds.) Thell.). Genet. Resour. Crop Evol. 1995, 42, 263-272. [CrossRef]

2. Singh, K.K.; Mridula, D.; Rehal, J.; Barnwal, P. Flaxseed: A potential source of food, feed and fiber. Crit. Rev. Food Sci. Nutr. 2011, 51, 210-222. [CrossRef] [PubMed]

3. Meagher, L.P.; Beecher, G.; Flanagan, V.; Li, B. Isolation and characterization of the lignans, isolariciresinol and pinoresinol, in flaxseed meal. J. Agric. Food Chem. 1999, 47, 3173-3180. [CrossRef] [PubMed]

4. Cunnane, S.C.; Ganguli, S.; Menard, C.; Liede, A.C.; Hamadeh, M.J.; Chen, Z.Y.; Wolever, T.M.S.; Jenkins, D.J.A. High alphalinolenic acid flaxseed (Linum usitatissimum): Some nutritional properties in humans. Br. J. Nutr. 1993, 69, 443-453. [CrossRef] [PubMed]

5. Mridula, D.; Kaur, D.; Nagra, S.S.; Barnwal, P.; Gurumayum, S.; Singh, K.K. Growth performance and quality characteristics of flaxseed-fed broiler chicks. J. Appl. Anim. Res. 2014, 43, 345-351. [CrossRef]

6. Connor, W.E. Importance of $\mathrm{n}-3$ fatty acids in health and disease. Am. J. Clin. Nutr. 2000, 71, 171S-175S. [CrossRef] [PubMed]

7. Mankevičienè, A.; Lugauskas, A.; Repečkienė, J.; Gruzdeviene, E. The effect of environmental conditions on the variation of fungi and mycotoxin contents in oil flax seed. Ekologija 2006, 3, 64-70.

8. Wirths, W.; Berglar, T.; Dieckhues, A.; Bauer, G. Fiber-rich snacks with reference to their effect on the digestive activity and blood lipids of the elderly. Z. Gerontol. 1985, 18, 107-110. [PubMed]

9. Mirshekari, M.; Amiri, R.; Nezhad, H.I.; Noori, S.A.S.; Zandvakili, O.R. Effects of Planting Date and Water Deficit on Quantitative and Qualitative Traits of Flax Seed. Am. Eurasian J. Agric Environ. Sci. 2012, 12, 901-913.

10. Casa, R.; Russell, G.; Cascio, B.L.; Rossini, F. Environmental effects on linseed (Linum usitatissimum L.) yield and growth of flax at different stand densities. Eur. J. Agron. 1999, 11, 267-278. [CrossRef]

11. Gusta, L.; O'Connor, B.; Bhatty, R. Flax (Linum usitatissimum L.) responses to chilling and heat stress on flowering and seed yield. Can. J. Plant. Sci. 1996, 77, 97-99. [CrossRef]

12. Battisti, D.; Naylor, R. Historical Warnings of Future Food Insecurity with Unprecedented Seasonal Heat. Science 2009, 323, 240-244. [CrossRef] [PubMed]

13. Kumar, A.; Pramanick, B.; Mahapatra, B.S.; Singh, S.P.; Shukla, D.K. Growth, yield and quality improvement of flax (Linum usitattisimum L.) grown under tarai region of Uttarakhand, India through integrated nutrient management practices. Ind. Crops Prod. 2019, 140, 111710. [CrossRef]

14. Sultana, C. The cultivation of fibre flax. Outlook Agric. 1983, 12, 104-110. [CrossRef] 
15. Pavelek, M.; Vrbová-Prokopová, M.; Ondráčková, E.; Ludvíková, M.; Griga, M. 17-Developments in fibrous flax and linseed breeding and cultivation. In Handbook of Natural Fibres, 2nd ed.; Kozłowski, R.M., Mackiewicz-Talarczyk, M., Eds.; Woodhead Publishing: Sawston, UK, 2020; pp. 605-692.

16. Sarada, C.; Alivelu, K.; Rao, V.S.; Babu, S.S.; Varaprasad, K. Oilseeds Statistics: A Compendium-2015; ICAR-Indian Institute of Oilseeds Research: Rajendranagar, Hyderabad, Telangana, India, 2015.

17. Pari, L.; Baraniecki, P.; Kaniewski, R.; Scarfone, A. Harvesting strategies of bast fiber crops in Europe and in China. Ind. Crops Prod. 2015, 68, 90-96. [CrossRef]

18. Ahmed, M.; Al-Doori, S. Influence of Sowing Dates on Growth, Yield and Quality of Some Flax Genotypes (Linum usitatissimum L.). Coll. Basic Educ. Res. J. 2012, 12, 733-746.

19. Siemens, B. Quality of Western Canadian Flaxseed; Canadian Grain Commission: Winnipeg, MB, Canada, 2017 ; pp. 1-13. 